\title{
In-silico investigations into natural products as non- nucleoside DNA methyltransferase 1 inhibitors for treating epi-mutation in gastric cancer
}

\author{
Dong-fang Li ${ }^{1}$, Rui-xiao Wang ${ }^{2}$, Yong-xia Yan ${ }^{1}$, Guo-liang Jin ${ }^{1}$, Guo-hui Song ${ }^{2}$, \\ Deng-bin $\mathrm{Ma}^{3}$ and Li Guan ${ }^{2 *}$ \\ ${ }^{1}$ Department of Radiotherapy, Hebei Cixian Cancer Hospital, Cixian 056500, Hebei Province, ${ }^{2}$ Handan City Kang Ye Biological \\ Technology Co. Ltd. Shiji Road, Han Dan City, Gao Kai District, He Bei Province, ${ }^{3}$ Department of Internal Medicine, Handan \\ City Hospital of Traditional Chinese Medicine, Hebei Province, China
}

*For correspondence: Email: guanligl@hotmail.com

\begin{abstract}
Purpose: To explore in silico methods to search for the best reported non-nucleoside DNA methyltransferase 1 (DNMT1) inhibitor of epimutation in gastric cancer.

Methods: A dataset of reported non-nucleoside DNMT1 inhibitors was used to target the active site of crystallized DNMT1 protein. Molecular docking simulations were carried out using AutoDock 4.2.6 I. The results were analyzed using Discovery studio visualizer.

Results: In silico analysis of known natural non-nucleoside DNMT1 inhibitors gave genistein as the top ranked compound with $\Delta G$ of $-6.39 \mathrm{Kcal} / \mathrm{mol}$. Further, the results indicated that epigallocatechin gallate and curcumin are poor non-nucleoside DNMT1 inhibitors, as the in silico data suggest that they failed to bind to the catalytic site of DNMT1.

Conclusion: The results indicate that genistein is the top rated compound for DNMT1 inhibition. Previous in vitro and in vivo work by other researchers seem to validate the findings of the study.
\end{abstract}

Keywords: Epi-mutation, DNA methyltransferase, Non-nucleoside, DNMT1 inhibitor, Docking

Tropical Journal of Pharmaceutical Research is indexed by Science Citation Index (SciSearch), Scopus, International Pharmaceutical Abstract, Chemical Abstracts, Embase, Index Copernicus, EBSCO, African Index Medicus, JournalSeek, Journal Citation Reports/Science Edition, Directory of Open Access Journals (DOAJ), African Journal Online, Bioline International, Open-J-Gate and Pharmacy Abstracts

\section{INTRODUCTION}

The inhibition of DNA methyltransferase1 (DNMT1) can be achieved by two inhibitory mechanisms: enzyme trapping achieved by nucleoside inhibitors and enzyme blocking by non-nucleoside inhibitors. A simple derivative of the nucleoside cytidine 5-azacytidine, is an archetypal DNMT1 inhibitor. The compound was first described more than four decades ago [1]. However, its demethylating activity was discovered later, in 1980 [2]. 5-azacytosine was shown to influence cellular differentiation by incorporation into DNA, and to acts as a nucleoside inhibitor [3]. However, this inhibitor was found to affect a variety of RNA functions and cause certain toxic effects [4]. Another DNMT1 inhibitor, 5-aza-2 ' -deoxycytidine (i.e., decitabine), is a deoxyribose analogue of 5azacytidine and has no effect on RNA function, but shows substantial toxic effects [5]. Another addition to the group of nucleoside DNMT1 inhibitors is zebularine [6], which is also a derivative of 5-azacytidine. This analog is more stable than others and its toxicity is less severe than the others [7]. 
In all of the above nucleoside DNMT1 inhibitors, toxicity is the only factor that poses a substantial drawback for their development as viable therapeutic agents. To overcome this limiting factor, non-nucleoside DNMT1 inhibitors can be used as epi-drugs. A number of non-nucleoside compounds have been shown to inhibit DNMT1 activity, including Caffeic acid, Curcumin, Daidzene, Epigallocatechin gallate, Genistein, Mahanine, Nanomycin, Parthenolide, and Psammaplin. The third type of DNMT1 inhibitorconsists of oligonucleotides (hairpin loops and specific antisense oligonucleotides) such as MG98. Hairpin loops have been used as competitor substrates for DNMT1 in mouse erythroleukemia cells, and they have shown the ability to induce the expression of p16 TSG in human HT29 colan carcinoma cells [8]. Transfection of human HCT116 and SW48 colon cancer cell lines with antisense oligonucleotides against DNMT1 resulted in the demethylation and reactivation of expression in p16 gene expression [9].

Epimutation involving downregulation of important tumor suppressor genes is a common anomaly in gastric cancers [10]. Epi-drugs of nucleoside origin are in use for treatment; however, non-nucleoside epi-drugs are in developmental stage. In silico studies have been used for epi-drug discovery [11-13]; in the present study, we used a similar approach to examine the possible binding mode of reported non-nucleoside DNMT1 inhibitors using AutoDock.

\section{EXPERIMENTAL}

\section{Dataset preparation}

Nine natural products, i.e, Caffeic acid, Curcumin, Daidzene, Epigallocatechin gallate, Genistein, Mahanine, Nanomycin, Parthenolide and Psammaplin, were selected for this study. The structures of these ten compounds are available from NCBI and were used for docking analyses. All were docked onto the active site, i.e., CYS1226, of DNMT1 using Auto Dock 4.2, and the result were analyzed using Accelrys discovery studio. The crystal structure of the catalytic site of human DNMT1 (accession: 3SWR) was retrieved from the protein databank (PDB). The retrieved structure was energy minimized using SPDB viewer at the default cutoff root mean square deviation (rmsd) of 0.30 Å using OPLS 2001 force field.

\section{Molecular docking simulation}

The selected compounds were analyzed using AutoDock to confirm the binding mode with the active site of the protein DNMT1 [14]. AutoDock energy values were calculated by characterization of intermolecular energy (which consists of van der Waals energy, hydrogen bonding energy, desolvation energy, and electrostatic energy), internal energy of the ligand, and torsional free energy. The docking energy was obtained from van der Waals energy and hydrogen bonding energy together, and the binding energy was built up from van der Waals energy and desolvation energy. Lamarckian genetic algorithm (GA) was considered for the run. For each ligand, $10 \mathrm{GA}$ runs were set, with 27,000 maximum generations, gene mutation rate of 0.02 , and crossover rate of 0.8 . A grid of $60 \times 60 \times 60$ points in $x, y$, and $z$ directions was built centered around the catalytic site of CYS1226. All the visualizations were carried out using Accelrys Discovery studio visualization.

\section{RESULTS}

The top nine non-nucleoside compounds selected for this study are shown in Table 1, and their structures are shown in Figure 1.

The result generated by the molecular docking analysis of nine known natural compounds are shown in Table 2.

Table 1: Known Natural DNMT inhibitors with target information

\begin{tabular}{llcc}
\hline S/N & Compound & Target & Reference \\
\hline 1 & Caffeic acid & DNMT1 & {$[15]$} \\
2 & Curcumin & DNMT1 & {$[16]$} \\
3 & Daidzene & DNMT1 & {$[17]$} \\
4 & Epigallocatechin gallate & DNMT1 & {$[18]$} \\
5 & Genistein & DNMT1 & {$[19]$} \\
6 & Mahanine & DNMT1 & {$[20]$} \\
7 & Nanomysin & DNMT3B & {$[21]$} \\
8 & Psammaplins & DNMT1 & {$[22]$} \\
9 & Parthenolide & DNMT1 & {$[23]$} \\
\hline
\end{tabular}

The data generated by analysis of these compounds with recently developed crystallographic structure showed that daidzene was the only compound interacting with the active site CYS1226, epigallocatechin gallate showed no interaction with the DNMT1 protein. The 3D plot of the interactions between the daidzen and the DNMT1 is given in Figure 2.

Among the selected known non-nucleoside DNMT1 inhibitors, geneistein was the only 

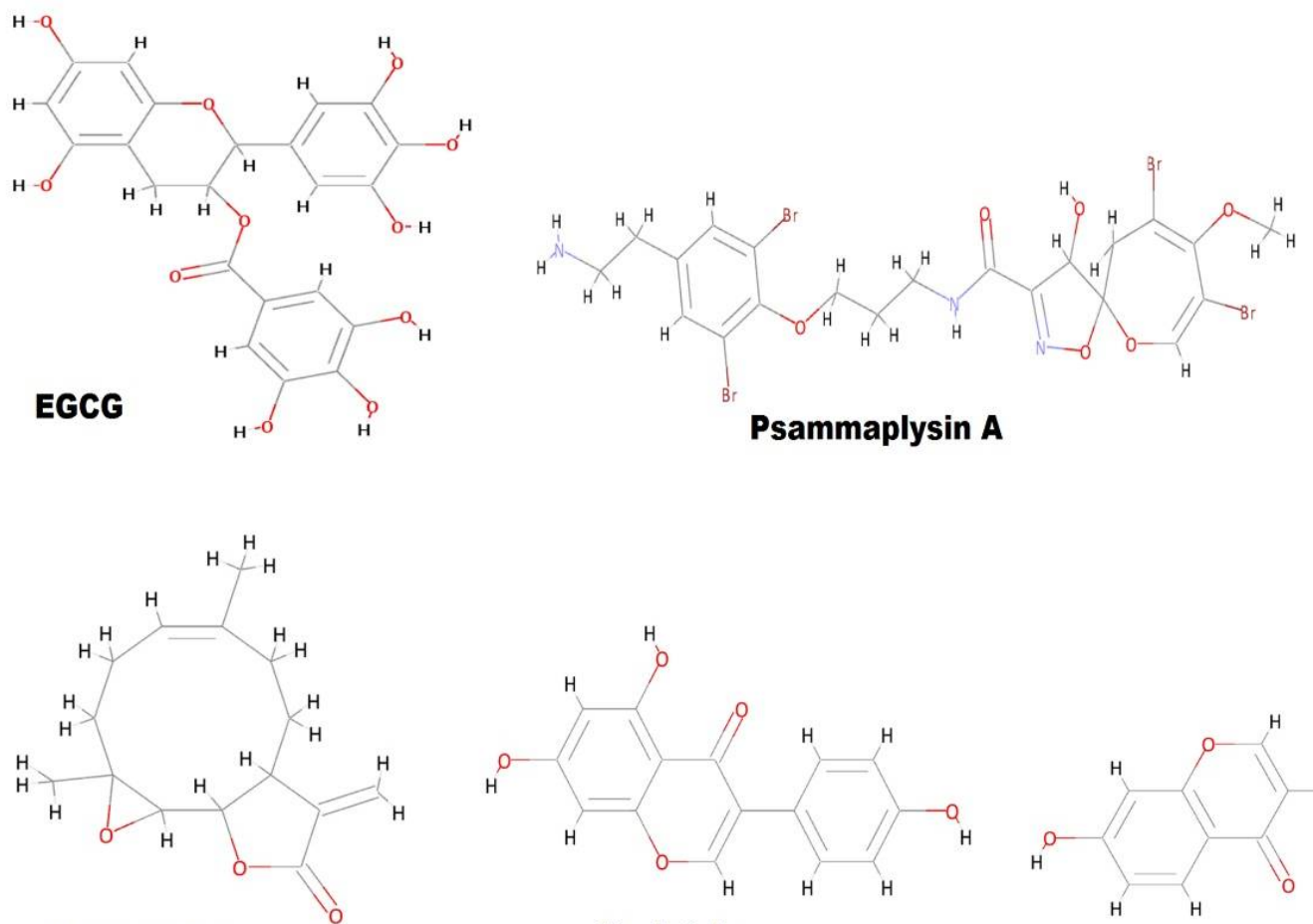

Parthenolide

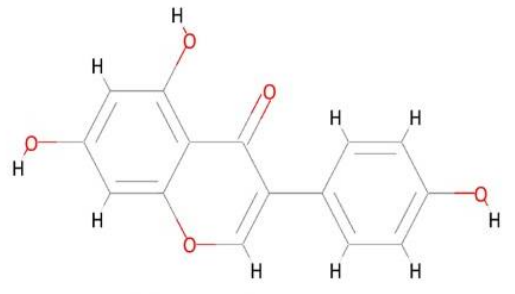

Genistein

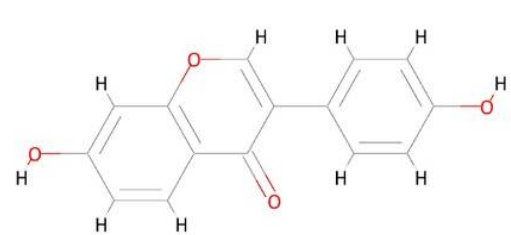

Diadzien
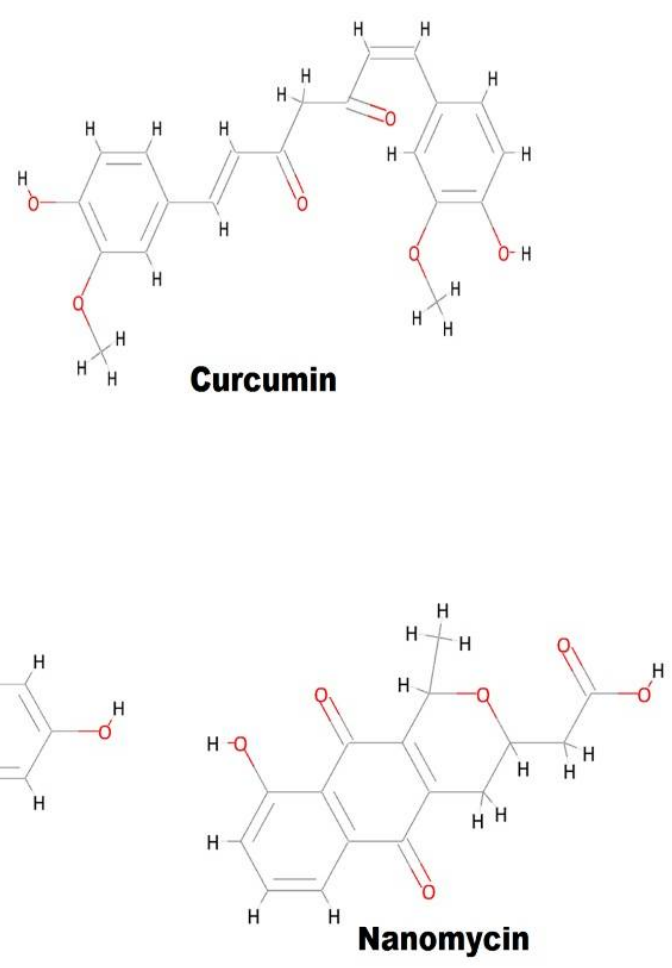

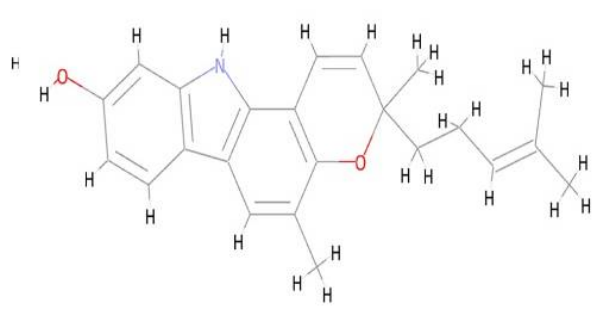

Mahanine

Figure 1: Two dimensional structures of reported non-nucleoside compounds 
Table 2: Molecular docking analysis of known Natural non-nucleoside DNMT1 Inhibitor

\begin{tabular}{|c|c|c|c|c|}
\hline NAME & Chem ID & $\begin{array}{c}\Delta \mathbf{G} \\
\mathrm{Kcal} / \mathrm{mol}\end{array}$ & Ligand binding pocket & H-bonds \\
\hline Curcumin & 969516 & -4.5 & $\begin{array}{l}\text { LYS1242, PHE1229, SER1246, } \\
\text { PRO1225, LEU1247, GLN1227, } \\
\text { GLU698, MET696, ASN646 }\end{array}$ & Curcumin:H40 - :ASN646:O(2.02 A $)$ \\
\hline Caffeic acid & 689043 & -5.32 & $\begin{array}{l}\text { MET696, PHE648, LYS649, } \\
\text { GLN1227, GLY1231, SER1230, } \\
\text { PHE1229, GLY1228, ARG651 }\end{array}$ & $\begin{array}{l}\left.\text { LYS649:NZ - :Caffeic acid:O3(2.64 A } \mathrm{A}^{\circ}\right) \\
\text { GLN1227:NE2 - :Caffeic acid:O3(3.12 A }) \\
\text { SER1230:N - :Caffeic acid:O2 }\left(2.98 \mathrm{~A}^{\circ}\right) \\
\text { SER1230:N:B - :Caffeic acid:O2 }\left(2.98 \mathrm{~A}^{\circ}\right)\end{array}$ \\
\hline Daidzene & 5281708 & -7.5 & $\begin{array}{l}\text { CYS1226, PRO1224, GLY1223, } \\
\text { PRO1225, ASN1267, GLU1266, } \\
\text { VAL1268, PHE1145, ARG1312, } \\
\text { ASN1578, SER1146, GLY1147, } \\
\text { CYS1148, GLY1150,GLY1149, } \\
\text { ALA1579 }\end{array}$ & $\begin{array}{l}\text { Daidzein:H28 - :PRO1224:O }\left(2.28 \mathrm{~A}^{\circ}\right) \\
\text { Daidzein:H29 - :SER1146:O(2.04 A }) \\
\text { GLY1150:N - :Daidzein:O4(3.01 A }) \\
\text { GLY1149:N - :Daidzein:O4(2.77 A })\end{array}$ \\
\hline $\begin{array}{l}\text { Epigallocatec } \\
\text { hin gallate }\end{array}$ & 65064 & -0.52 & $\begin{array}{l}\text { MET696, LYS1242, GLN1227, } \\
\text { LEU1247, PHE1229, ASN1245, } \\
\text { VAL1248, CYS1226, PRO1225, } \\
\text { SER1246, GLU698, PHE648 }\end{array}$ & \\
\hline Genistein & 5280961 & -6.39 & $\begin{array}{l}\text { GLY1147, SER1146, CYS1148, } \\
\text { GLY1149, ALA1579, GLY1150, } \\
\text { PHE1145, PRO1225, GLY1223, } \\
\text { CYS1226, PRO1224, ALA699, } \\
\text { ASN1267, GLU1266, ARG1312, } \\
\text { ASN1578 }\end{array}$ & $\begin{array}{l}\text { CYS1148:N - :Genistein:O5(3.16 A }) \\
\text { GLY1149:N - :Genistein:O5(2.83 A }) \\
\text { CYS1226:N - :Genistein:O4(3.07 A }) \\
\text { Genistein:H30 - :SER1146:O }\left(1.81 \mathrm{~A}^{\circ}\right) \\
\left.\text { Genistein:H28 - :GLU1266:OE2(2.45 } \mathrm{A}^{\circ}\right)\end{array}$ \\
\hline Mahanine & 56674845 & -7.4 & $\begin{array}{l}\text { GLN1227, ALA699,PRO1225, } \\
\text { GLY 1223, GLU1266, SER1146, } \\
\text { LEU1151, VAL1580, GLY1150, } \\
\text { PHE1145, GLY1147, ALA1579, } \\
\text { GLY1149, CYS1148, GLU698, } \\
\text { ASN1578 }\end{array}$ & $\begin{array}{l}\text { GLY1150:N - :Mahanine:O2(2.95 A }) \\
\left.\text { LEU1151:N - :Mahanine:O2(3.10 A }{ }^{\circ}\right) \\
\text { Mahanine:H48 - :SER1146:O }\left(2.34 \mathrm{~A}^{\circ}\right)\end{array}$ \\
\hline Nanomycin & 40586 & -6.78 & $\begin{array}{l}\text { LYS649, PHE648, ASN646, } \\
\text { PRO1225, GLN1227, LEU1247, } \\
\text { SER1246, LYS1242, PHE1229 }\end{array}$ & LYS1242:NZ - :Nanomysin:O6(3.01 A) \\
\hline Parthenolide & 6473881 & -6.34 & $\begin{array}{l}\text { GLY1223, CYS1226,ALA699, } \\
\text { ASP700, VAL1268, ASN1267, } \\
\text { ARG1312, GLU1266, ASN1578, } \\
\text { PHE1145, PRO1225, }\end{array}$ & \\
\hline Psammaplin & 6400741 & -3.37 & $\begin{array}{l}\text { PRO1225, PRO1224, ASN1578, } \\
\text { VAL1268, ASP700, ASN1267, } \\
\text { GLY1223, GLU1168,PHE1145, } \\
\text { MET1169,LEU1247, ASN1245, } \\
\text { MET696, GLN1227 }\end{array}$ & $\begin{array}{l}\text { VAL1268:N - :Psammaplin:O7(2.93 A }) \\
\text { Psammaplin:H60 - :GLN1227:OE1(2 A }) \\
\text { Psammaplin:H57 - :ASN1267:OD1 }\left(2 \mathrm{~A}^{\circ}\right)\end{array}$ \\
\hline
\end{tabular}

compound that showed non covalent (hydrogen bond) interaction with the active site CYS1226 of the enzyme DNMT1. All other compounds except Epigallocatechin gallate showed interaction with other amino acids in the cytosine binding groove. Genestein (chem. ID 5280961) has a $\Delta G$ of -6.39 $\mathrm{Kcal} / \mathrm{mol}$ and forms five hydrogen bond with cytosine binding pocket of DNMT1. The binding pocket in this case comprises the following amino acids: GLY1147, SER1146, CYS1148, GLY1149, ALA1579, GLY1150, PHE1145, PRO1225, GLY1223, CYS1226, PRO1224, ALA699, ASN1267, GLU1266, ARG1312 and ASN1578.

The $\mathrm{O}^{4}$ position of the genestein interacts with CYS1226, and the bond formed between them has a distance of $3.07 \mathrm{~A}^{\circ}$. Figure 3 spotlights on the binding scaffold of cysteine in DNMT1 and shows its interaction with genestein.

Figure 4 shows five different interactions. The first interaction is discussed is that of active site CYS1226 and Oxygen at $4^{\text {th }}$ position of genestein. The oxygen atoms are represented by red mesh and interact at two positions- one has already discussed, and the other is the interaction of oxygen at the $5^{\text {th }}$ position with GLY1149. In addition, three more interactions were observed, all of which, except that with GLU1266 arose from the same oxygen at position 5 . The shortest interaction is that of $30^{\text {th }}$ hydrogen of genistein and the oxygen atom of SER1146. This result generated by molecular docking of genestien onto the catalytic site of DNMT1 implies that this particular non- 
nucleoside DNMT1 inhibitor has a better chance of reverting epimutation than any other known natural non-nucleoside inhibitors. Further analysis indicated that Epigallocatechin gallate is over hyped non-nucleoside DNMT1 inhibitor, as the results showed that it fails to interact with the catalytic scaffold of DNMT1.

\section{DISCUSSION}

Genistein is known to protect against colon cancer by increasing gene expression of several WNT signaling components by demethylating their promoter [24]. Genistein is also known to show effects similar to those of 5 Aza-cytidine,
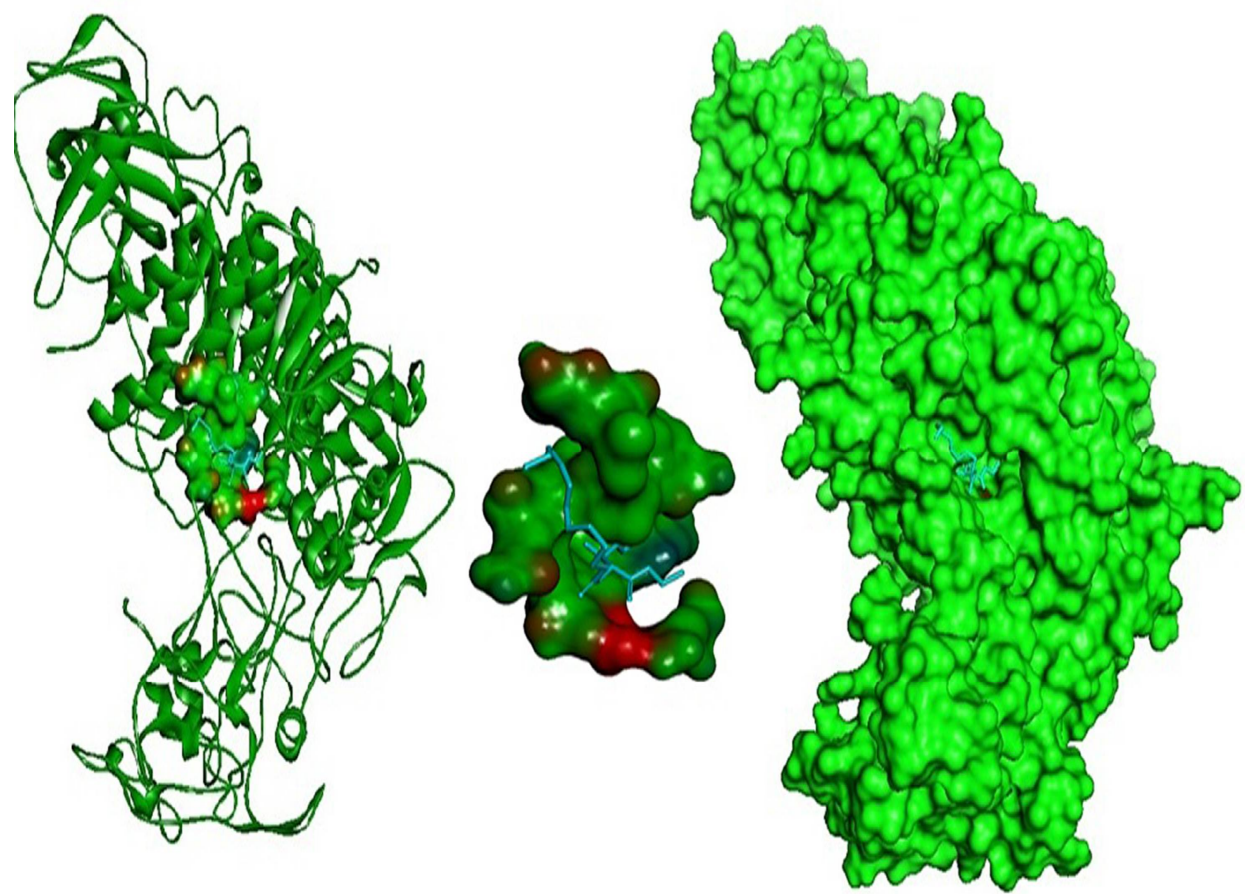

Figure 2: Three dimensional representation of binding mode of the top non-nucleoside DNMT1 inhibitors with the catalytic active site of DNMT1

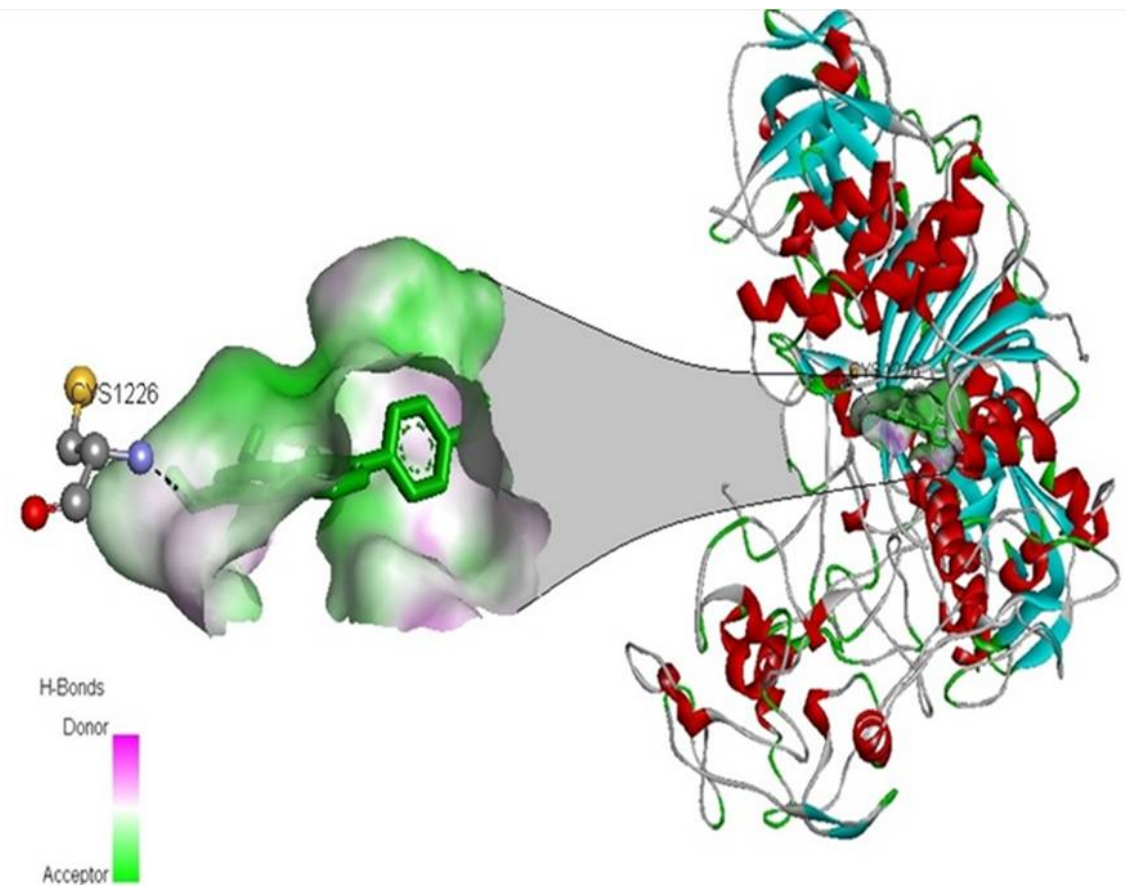

Figure 3: The best docked conformation of genistien in the active site of DNMT1 


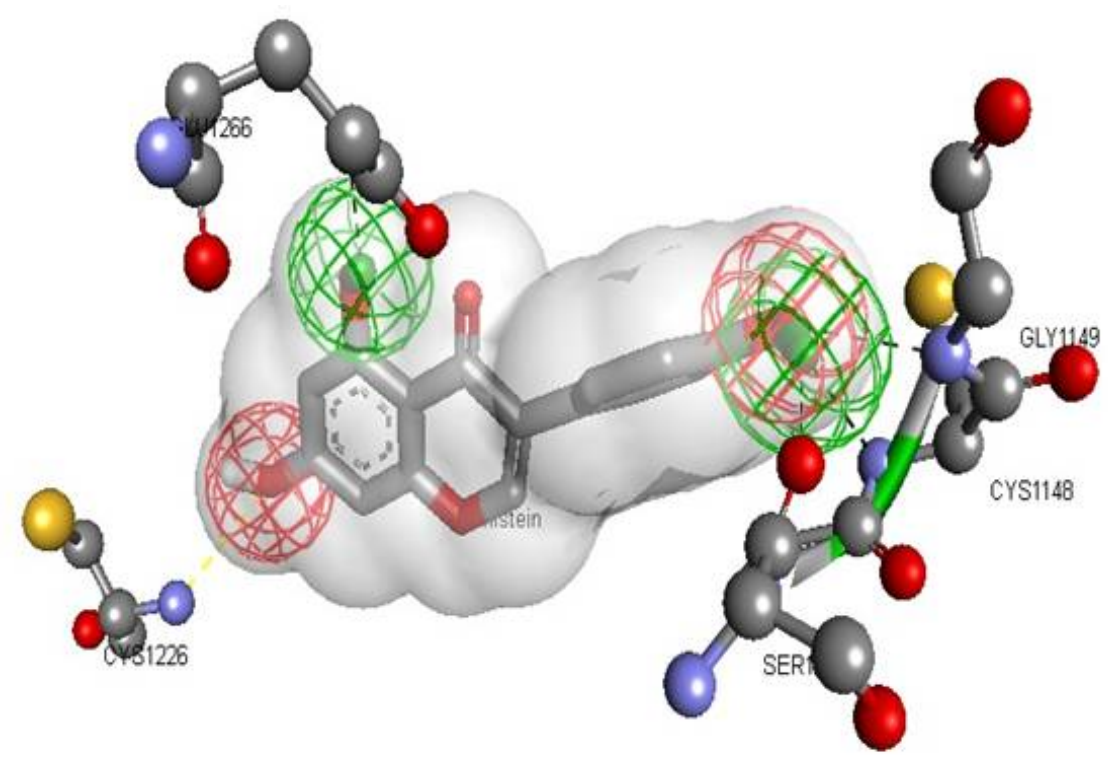

Figure 4: The non-covalent interaction of genestein with five amino acids of DNMT1

which is currently undergoing phase 2 clinical trials as a treatment for prostate cancer. The demethylating activity of the green tea polyphenol Epigallocatechin gallate is controversial.

The experimental evidence supporting DNA demethylation in human cancer cells was limited to only indirect PCR analyses of only few cancerassociated genes [18] and the effect could not be reproduced by direct experimental approaches. In addition, it has been noted that Epigallocatechin gallate is a highly reactive compound that may inhibit DNA methylation nonspecifically and/or indirectly. Further, MedinaFranco [11] suggested that Epigallocatechin gallate should not be considered as DNMT1 inhibitor.

Curcumin is other natural compound, the potential of which is over estimated [16]; subsequent studies on this particular compound also showed that it fails to induce promoter hypomethylation [11]. These previous result were validated by our molecular docking analysis of the crystallographic structure of the catalytic site of DNMT1 indicating that curcumin showed only one interaction i.e. with ASN649.All the compounds examined other that genestien showed weak interaction with the catalytic binding pocket of DNMT1, and the results of in vitro and in vivo studies also tend to agree with our in-silico results.

\section{CONCLUSION}

The findings of this study provide and atomic insight into the binding mode of known natural non-nucleoside DNMT1 inhibitors. The results generated are useful for identifying the topranking non-nucleoside DNMT1 inhibitor using in silico methodologies. Genistein shows the greatest inhibitory effect, and in vitro and in vivo studies of the same compounds by other researchers seem to validate these findings. Further, the results also indicate that epigallocatechin gallate and curcumin have been overestimated as potential non-nucleoside DNMT1 inhibitors as their in silico data generated by our approach suggest that they fail to bind to the catalytic site of DNMT1. Thus, this study provides a suitable, efficient and economically viable method to screen for novel non-nucleoside DNMT1 inhibitors.

\section{DECLARATIONS}

\section{Conflict of Interest}

No conflict of interest associated with this work.

\section{Contribution of Authors}

The authors declare that this work was done by the authors named in this article and all liabilities pertaining to claims relating to the content of this article will be borne by them.

\section{Open Access}

This is an Open Access article that uses a funding model which does not charge readers or their institutions for access and distributed under the terms of the Creative Commons Attribution License (http://creativecommons.org/licenses/by 
14.0) and the Budapest Open Access Initiative (http://www.budapestopenaccessinitiative.org/rea d), which permit unrestricted use, distribution, and reproduction in any medium, provided the original work is properly credited.

\section{REFERENCES}

1. Šorm F, Piskala A, Čihák A, Veselý J. 5-Azacytidine, a new, highly effective cancerostatic. Experientia. 1964; 20(4): 202-203.

2. Jones PA, Taylor SM. Cellular differentiation, cytidine analogs and DNA methylation. Cell. 1980; 20(1): 85-93.

3. Santi DV, Norment A, Garrett CE. Covalent bond formation between a DNA-cytosine methyltransferase and DNA containing 5-azacytosine. Proc Natl Acad Sci U S A. 1984; 81(22): 6993-6997.

4. Issa J-PJ, Gharibyan V, Cortes J, Jelinek J, Morris G, Verstovsek S, Talpaz M, Garcia-Manero G, Kantarjian HM. Phase II study of low-dose decitabine in patients with chronic myelogenous leukemia resistant to imatinib mesylate. J Clin Oncol. 2005; 23(17): 3948-3956.

5. Jüttermann R, Li E, Jaenisch R. Toxicity of 5-aza-2'deoxycytidine to mammalian cells is mediated primarily by covalent trapping of DNA methyltransferase rather than DNA demethylation. Proc Natl Acad Sci U S A. 1994; 91(25): 11797-11801.

6. Cheng JC, Matsen CB, Gonzales FA, Ye W, Greer $S$, Marquez VE, Jones $P A$, Selker EU.Inhibition of DNA methylation and reactivation of silenced genes by zebularine. J Natl Cancer Inst. 2003; 95(5): 399-409.

7. Flynn J, Fang J-Y, Mikovits JA, Reich NO. A potent cellactive allosteric inhibitor of murine DNA cytosine C5 methyltransferase. J Biol Chem. 2003; 278(10): 82388243.

8. Robert M-F, Morin S, Beaulieu N, Gauthier F, Chute IC, Barsalou A, MacLeod AR. DNMT1 is required to maintain CpG methylation and aberrant gene silencing in human cancer cells. Nat Genet. 2003; 33(1): 61-65.

9. Ting $A H$, Jair $K-w$, Suzuki $H$, Yen R-WC, Baylin $S B$, Schuebel KE. CPG island hypermethylation is maintained in human colorectal cancer cells after RNAimediated depletion of DNMT1. Nat Genet. 2004; 36(6): 582-584.

10. Wu P-Y, Zhang Z, Wang J-M, Guo W-W, Xiao N, He Q, Wang YP, Fan YM. Germline promoter hypermethylation of tumor suppressor genes in gastric cancer. World J Gastroenterol. 2012; 18(1): 70-78.

11. Medina-Franco JL, López-Vallejo F, Kuck D, Lyko F. Natural products as DNA methyltransferase inhibitors: a computer-aided discovery approach. Mol Divers. 2011; 15(2): 293-304.

12. Chikan NA, Bhavaniprasad V, Anbarasu K, Shabir N, Patel TN. From natural products to drugs for epimutation computer-aided drug design. Appl Biochem Biotechnol. 2013; 170(1): 164-175.

13. Chikan NA, Vipperla B. KAISO inhibition: an atomic insight. J Biomol Struct Dyn. 2015; 33(8): 1794-1804.

14. Goodsell DS, Morris GM, Olson AJ. Automated docking of flexible ligands: applications of AutoDock. J Mol Recognit. 1996; 9(1): 1-5.

15. Lee WJ, Zhu BT. Inhibition of DNA methylation by caffeic acid and chlorogenic acid, two common catecholcontaining coffee polyphenols. Carcinogenesis. 2006; 27(2): 269-277.

16. Liu Z, Xie Z, Jones W, Pavlovicz RE, Liu S, Yu J, Li PK, Lin J, Fuchs JR, Marcucci G, Li C, Chan KK. Curcumin is a potent DNA hypomethylation agent. Bioorg Med Chem Lett. 2009; 19(3): 706-709.

17. Choi KY, Kim Tj, Koh SK, Roh CH, Pandey BP, Lee N, et al. A-ring ortho-specific monohydroxylation of daidzein by cytochrome P450s of Nocardia farcinica IFM10152. Biotechnol J. 2009; 4(11): 1586-1595.

18. Fang MZ, Wang $Y$, Ai N, Hou Z, Sun Y, Lu H, Welsh W, Yang CS. Tea polyphenol (-)-epigallocatechin-3-gallate inhibits DNA methyltransferase and reactivates methylation-silenced genes in cancer cell lines. Cancer Res. 2003; 63(22): 7563-7570.

19. Day JK, Bauer AM, Zhuang Y, Kim B-E, Newton LG, Nehra $V$, Forsee KM, MacDonald RS, Besch-Williford $C$, Huang TH, Lubahn DB.Genistein alters methylation patterns in mice. J Nutr. 2002; 132(8): 2419S-2423S.

20. Sheikh KD, Banerjee PP, Jagadeesh S, Grindrod SC, Zhang L, Paige M, Brown ML. Fluorescent epigenetic small molecule induces expression of the tumor suppressor ras-association domain family $1 \mathrm{~A}$ and inhibits human prostate xenograft. J Med Chem. 2010; 53(6): 2376-2382.

21. Kuck D, Caulfield T, Lyko F, Medina-Franco JL. Nanaomycin A selectively inhibits DNMT3B and reactivates silenced tumor suppressor genes in human cancer cells. Mol Cancer Ther. 2010; 9(11): 3015-3023.

22. Pina IC, Gautschi JT, Wang G-Y-S, Sanders ML, Schmitz FJ, France $D$, Cornell-Kennon $S$, Sambucetti $L C$, Remiszewski SW, Perez LB, Bair KW, Crews P. Psammaplins from the Sponge Pseudoceratina $p$ urpurea: Inhibition of Both Histone Deacetylase and DNA Methyltransferase. J Med Chem. 2003; 68(10): 3866-3873.

23. Liu Z, Liu S, Xie Z, Pavlovicz RE, Wu J, Chen P, Aimiuwu $J$, Pang J, Bhasin D, Neviani $P$, et al. Modulation of DNA methylation by a sesquiterpene lactone parthenolide. J Pharmacol Exp Ther. 2009; 329(2): 505514

24. Wang Z, Chen H. Genistein increases gene expression by demethylation of WNT5a promoter in colon cancer cell line SW1116. Anticancer Res. 2010; 30(11): 45374545 . 